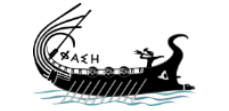

journal.phaselis.org
PHAS LLIS

Issue V (2019)
Disiplinlerarası Akdeniz Araştırmaları Dergisi

Journal of Interdisciplinary Mediterranean Studies

\title{
Roma Cumhuriyet Dönemi Emperyalizmi ve Yakın Doğu Emperyalist Politikaları Üzerine Bazı Değerlendirmeler
}

\author{
Some Considerations on The Imperialism of Roman Republic \\ And Its Emperialistic Policies Over The Near East
}

\author{
Muzaffer DEMiR \\ (D) https://orcid.org/0000-0001-7270-2317
}

open 2 access journals

The entire contents of this journal, Phaselis: Journal of Interdisciplinary Mediterranean Studies, is open to users and it is an 'open access' journal. Users are able to read the full texts, to download, to copy, print and distribute without obtaining the permission of the editor and author(s). However, all references to the articles published in the e-journal Phaselis are to indicate through reference the source of the citation from this journal.

Phaselis: Journal of Interdisciplinary Mediterranean Studies is a peer-reviewed journal and the articles which have had their peer reviewing process completed will be published on the web-site (journal.phaselis.org) in the year of the journal's issue (e.g. Issue IV: JanuaryDecember 2018). At the end of December 2018 the year's issue is completed and Issue V: January-December 2019 will begin.

Responsibility for the articles published in this journal remains with the authors.

(c) This work is licensed under a Creative Commons Attribution-
NonCommercial-ShareAlike 4.0 International License.

Citation M. Demir, "Roma Cumhuriyet Dönemi Emperyalizmi ve Yakın Doğu Emperyalist Politikaları Üzerine Bazı Değerlendirmeler". Phaselis V (2019) 315-332.

http://dx.doi.org/10.18367/Pha.19020

Received Date: 09.10.2019 | Acceptance Date: 07.11.2019

Online Publication Date: 26.12.2019

Editing Phaselis Research Project

www.phaselis.org 


\title{
Roma Cumhuriyet Dönemi Emperyalizmi ve Yakın Doğu Emperyalist Politikaları Üzerine Bazı Değerlendirmeler
}

\author{
Some Considerations on the Imperialism of Roman Republic and Its Emperialistic \\ Policies over the Near East
}

\author{
Muzaffer DEMiR *
}

Öz: Roma'nın Yakındoğu'ya yönelik emperyal politikalarını yorumlayan modern çalışmaların, Doğu kültürlerini önyargılı bir şekilde barbar, öteki olarak gören ve genelde güçlü aristokratların görüşlerini yansıtan Roma ve Hellen kökenli antik yazarların verilerinden hareket ederek bazı çıkarımlarda bulundukları görülmektedir. Son zamanlarda her ne kadar bu önyargılı antik kaynaklara yönelik eleştirel yorumlar söz konusu olsa da, tarafsız yorumlama konusunda belli bir direncin de devam ettiği gözlemlenmektedir. Bu bağlamda, hala tartışma konusu olsa da, W. Harris'in "War and Imperialism in Republican Rome 327-70 BC" başıkılı çalışmasında sunduğu bakış açıları daha nesnel görünmektedir. Biz bu çalışmamızda Harris'in ilgili görüşlerini destekler içerikte Roma Cumhuriyeti'nin MÖ I. yüzyılın ilk yarısında Anadolu'nun güney kıyılarındaki sözde korsanlıkla mücadelesi ve Yakındoğu'da MÖ 53 yılında Parthlara karşı gerçekleşen Carrhae Muharebesi'nin sebepleriyle ilgili iki örneklemeyi açıklamaya çalışacağız.

Anahtar sözcükler: Roma Cumhuriyeti, Emperyalizm, Yakın Doğu, Korsanlık, Carrhae

Abstract: The modern works interpreting the imperialistic policies of Rome towards the Near East appear to have made some of their inferences from the works of ancient Greek and Roman writers who in general not only reflected the views of aristocrats and but also saw the Eastern cultures as marginalised and barbarian. Although in recent years the inferences based on the precudicious views of these ancient writers have been critisized, it appears that there is still a reaction as regard to the impartial interpretation. Within this context, it seems that W. Harris's approaches in his work titled as "War and Imperialism in Republican Rome 327-70 BC" are more objective, though still debated. In this work, in line with the relative views of Harris, we shall strive to explain the two cases; (a) Roman Republic's so-called struggle with the piracy in southern Anatolian coasts during the first half of the $1^{\text {st }}$ century $B C$, (b) the reasons of the war of Carrhae in $53 \mathrm{BC}$ against the Parthians in the Near East.

Keywords: Roman Republic, Imperialism, Near East, Piracy, Carrhae

\footnotetext{
Prof. Dr., Muğla Sıtkı Koçman Üniversitesi, Edebiyat Fakültesi, Tarih Bölümü, Muğla. dmuzaffer68@gmail.com (1) https://orcid.org/0000-0001-7270-2317

Bu çalışmanın özeti 06-08 Nisan 2016 tarihleri arasında Samsun/Canik'te "Medeniyetler Merkezi ve Büyük Güçlerin Hedefi Ortadoğu" teması üzerine düzenlenen "IX. Uluslararası Canik Sempozyumu”nda sunulmuş yayın için verilmemiştir.
} 
Tacitus, MS 80'li yıllarda kendilerini fethetmeye ve köleleştirmeye gelen Romalılara karşı Galcacus adlı bir Briton liderinin ağzından şu sözlerle savaş çağrısı yapıldığını bildirmektedir:

“...Bizim ötemizde kabileler yoktur, gerçekte sadece dalgalar ve kayalıklar bulunmaktadır. Bunların dışında baskılarından kaçışın sadece itaat ve boyun eğmeyle gerçekleşeceği daha korkunç olan Romalılar bulunmaktadır. [Onlar] dünyanın hırsızlarıdırlar, evrensel talanlarıyla toprağı helak etmişlerdir ve denizlere de gözlerini dikmişlerdir. Eğer düşman zenginse [Romalılara göre] açgözlüdürler, dolayısılla soyulmayı hak etmektedirler; eğer düşman fakirse [Romalılar] onlara hükmetme ve köleleştirme şehvetine kapılmaktadır; ne Doğu ne de Batı onları [Romalıları] tatmin edebilmiştir. Fetih hırsları için zenginlikten ve fakirlikten eşit, cezb edici şekilde yemlenebilme güdüsüne sahip dünyadaki tek insanlardır. Sahte yönetimlerini hırsızlık, katliam ve zorbalıkla yürütmektedirler ve aslında çölleştirdikleri yerlere barışçl bir hava kattıkları izlenimi vermektedirler"'.1.

Bu sözlerin Tacitus'un kendi görüşlerini yansıtma olasılığı üzerinde durulması gerekmektedir. Onun Roma yönetim tarzına karşı bu kadar sert eleştiriler getirmiş olması gerçekten ilgi çekicidir. O, belki de gücü elinde tutan imparator Domitianus (MS 81-96) da dâhil, "imparatorlar merkezli" yozlaşma politikalarına karşı çıktığından, böylesine bir görüş belirtmeye cesaret etmiş, kendi konfor bölgesinden fırsat bulduğunda çıkarak eleştirel bir yaklaşım sergilemiş olmalıdır. Onun yazıları yaşadığı dönem itibarıyla yozlaşma, hükümet skandalı ve imparatorların güç hırsından dolayı yıkıma uğratılan veya isimleri kirletilen masum insanların hikâyeleriyle doludur. Aynı zamanda bir Roma vatandaşı olan Tacitus'un kendisine karşı tepkileri de göz önüne alarak, korkmadan Germen liderden Cagalus'un böylesine bir anlatım sergileyen söylevini alıntılaması, Romalıların bile onun ifşa ettiği yöndeki yönetimsel özelliklerini normal karşıladıkları iması doğurabilmektedir. Doğal olarak burada ilginç olan bir diğer nokta da Tacitus'un ağzından Roma emperyalizminin acımasızlığını ortaya koyan Briton veya Britanyalıların 17-19. yüzyıllarda Romalıları örnek alarak Hindistan, Afrika, Amerika ve Ortadoğu'da benzer politikalarla kendi emperyalist emellerini gerçekleştirmiş olmalarıdır². Bu durum, Augustus'un Pax Romana dönemini dışarıda tutacak olursak, Roma'nın Cumhuriyet Dönemi'nden itibaren saldırgan, savaşı arzu eden politikalarına benzer şekilde ABD’nin bariz bir şekilde özellikle Orta Doğu coğrafyasında 19. yüzyı sonlarından itibaren uygulamaya başladığı ve devam ettiği politikalarında da kendisini göstermektedir.

Tacitus'a göre MS I. yüzyılda acımasız bir Roma emperyalizmi gerçeği bulunmaktadır. Ancak onun bu tespitlerinin ne kadar doğruyu yansıttığı tartışmaya açıktır. Zaten karmaşık bir konu olan Roma emperyalizminin ne kadar acımasız olduğu meselesini tam anlamıyla açıklığa kavuşturmak zordur. Bu konuda yapılan ilk modern çalışmalarda Roma emperyalizmini meşrulaştırma yönündeki görüşlere öncelik verilmiştir. Bu görüşlerden birincisi Philhellenizm teorisidir. Philhellenizm kelimenin tam anlamıyla Hellenlerle ilgili şeyleri sevmek anlamına gelmektedir.

1 Tac. Agr. XXX. Bu yüzden, Karadeniz kralı VI. Mithradates, Romalıları insanlığın baş düşmanı olarak tanımlıyordu (Welles 1934, 295 vdd. $n^{\circ}$ 74; ayrıca bkz. Arslan 2007, 118 vd. dn 334). Ayrıca Livius (XXIII. 42. 10), Romalıların II. Kartaca Savaşı sırasında Samnit toprakları içinde serbest dolaşan haydutlar gibi hareket ettiklerini belirtmektedir. Praedones (hırsızlar veya korsanlar) tarzında talan etme hakkında bkz. Caes. Bel. Civ. III. 112. Roma iç çekişmeleri sırasındaki latrocinii (haydut çeteler) hakkında ayrıca bkz. Cic. Pis. XXVI; Catil. I. 31; Phil. XIV. 10; Att. IV. 3. Eski

Roma emperyalizminin Britanya kolonizmi veya post-kolonizminin meşrulaştırılması ve mantıklı kılınması doğrultusunda kavranması konusundaki tartışmalar için bkz. Dimitriev 2009. 
Roma, MÖ II. yüzyılın başlarından itibaren Makedonya Krallığı ve Hellen kentlerinin iç işlerine müdahale etmeye başladıktan sonra Hellen kültürü ile birebir etkileşim içine girmiş ve bu kültürün üstünlüğüne değer vermeye başlamıştır. Bunun sonucunda Roma'nın güçlü, tehlikeli Hellenistik krallıklara karşı anakara Hellen kentlerini korumak ve otonomilerini devam ettirmek için bir seri savaşa girdiği düşünülmektedir. Halbûki aynı Roma, özellikle Hellas anakarasına müdahale etme ve egemenlik altına alma aşamalarında Makedonyalılarla işbirliği yaptıkları gerekçesiyle Korinthos ve Thebai gibi kentleri büyük bir katliam sonucunda yok etmiştir. Ayrıca M. P. Cato gibi Hellen kültüründen nefret eden senatörler Roma siyasetinde etkin bir rol oynamışlardır. Hatta Roma kendi kuruluş efsanesini dahi herhangi bir Hellen kentine değil de, Hellenlerin barbar olarak gördükleri Anadolu'daki Troia kentinden kaçanlara bağlamıştır ${ }^{3}$. Bunlar Romalıların Hellen kültürüne o kadar da sevgi beslemediklerinin sadece birkaç örneğini oluşturmaktadır. İkincisi diplomatik karmaşıkıklar teorisidir. Roma açısından güven, onur ve inanç kavramları çok önemli olduğundan dış siyasette vaadini tutmaya çok büyük değer verdiği iddia edilmektedir. Bu sebeple Roma, zaman içinde yabancı devletlerle yapılan anlaşmalar sonucunda bir takım problemlerin içine çekilmiştir. Oysaki Roma'nın özellikle Hellen kent devletlerinde bilinçli olarak elitlerin işbirliğiyle problemleri kendisinin körükleyip ortalığı karıştırdığını ve böylelikle buralara müdahale etme ve onları ekonomik açıdan sömürme fırsatını yakaladığını teyit edecek deliller bulunmaktadır. Ayrıca Roma, yeri geldiğinde sırf çıkarı için yapmış olduğu anlaşmaların kuralları ve düzenlemelerinden (ius fetiale) de işine gelmediğinde vazgeçmesini bilmiştir. Hellen dünyasının işlerine karışma politikasını zamana yaymış, zamanı gelince de kendi ekonomik sömürü politikası doğrultusunda gereğini yapmıştır.

Üçüncü olarak T. Mommsen tarafından öne sürülen 1970'li yılların başlarına kadar Batı́da kabul gören savunma emperyalizmi teorisine de bakılabilir ${ }^{4}$. Buna göre Roma Cumhuriyet Dönemi politikaları tehdite tehditle karşılık vererek sürekli dışa doğru sürüklenmek zorunda kalmıştır. Roma'nın başlangıçta topraklarını Italya Yarımadası'ndan deniz ötesine genişletmek gibi bir amacı yoktur. Bu görüşe karşın, aşağıda da açıklayacağımız üzere, Roma'nın sadece Yarımada içinde değil, dışında da oldukça saldırgan ve savaş arzulayan nitelikte bir tavır sergilediği ve ordularını gönderdiği bilinmektedir. Bu teori doğrultusunda Roma senatosunun MÖ II. yüzyılın ilk yarısında fethettiği yerleri eyalete dönüştürmediği, dolayısıyla sistematik olarak buraları sömürmediği iddiası öne sürülmüştür. Ancak herbir karar Roma’nın acil algılanan çıkarı doğrultusunda alındığından senatonun bu yönde karar vermesinin sebebi eyalete dönüştürme kararının hâli hazırda herhangi bir ekonomik fayda sağlamayacağı gerçeğine dayanabilir. Dolayısıyla Roma'nın yürüttüğü ve genelde uzun zaman dilimine yayarak yürütmekte ısrar ettiği herbir savaşın sebebi ve sonucu kendi içinde bulunulan şartlara ve koşullara göre iyi analiz edilmelidir.

Mommsen ve ona destek veren tarihçilerin görüşlerine 1970'li yıllardan sonra eleştiriler getiren eserler yazılmaya başlanmıştır. Bu doğrultuda Roma Cumhuriyet Dönemi emperyalizminin

3 MÖ III. yüzyıldan itibaren bazı Hellen yazarlarınki de dahîl edebi metinlerde Hellenlerle ilgili tek dilden kötü bir algının oluşturulduğu konusunda ayrıca bkz. Lomas 1996, 140-141.

4 Mommsen 1894. Ayrıca bkz. Frank 1914; Errington 1971; Walbank 1963, 1-13. A. N. Sherwin-White'ın benzer tartışmaları içeren Roman Foreign Policy in the East 168 B.C. to A. D. 1 (Norman 1984) başlıklı eserinde, Roma'nın Doğu'yu fethetmesiyle ilgili politikasının geçişlerini izah etme arayışı içine girmediği, sürekli saldırganlık suçlamalarına karşı, Romalıları savunmaya yöneldiği görülmektedir. Buna rağmen ticaretin önemine vurgu yaptığında emperyal politikanın oluşumu üzerine güçlü ekonomik baskılara vurgu yapmaktadır. Onun hem ekonomik faktörün önemine vurgu yapması hem de Roma savaş kararlarının düzenli olarak savunma karakterine sahip olduğu iddiası çelişki içermektedir. 
niteliklerini yeniden ele alan önemli bir kitap çalışması öne çıkmıştır. Bu W. Harris'in War and Imperialism in Republican Rome 327-70 BC (Oxford 1979) başlıklı eseridir. Harris, beş bölümden oluşan kitabında savunma ermperyalizmi teorisine ciddi eleştiriler getirmiştir. Harris'in eserinin temel iddiaları şöyledir: (a) Özellikle MÖ II. yüzyılın ortalarına kadar aristokrat ve alt sınıftaki Romalıların hem beklentileri hem de sosyal değerler sistemi düzenli savaşlar icraatına göre uyarlanmıştır; onlar bu hayat tarzıyla birlikte süregiden davranışlara ve alışkanlıklara sahiptirler, dolayısıyla savaşlar Roma hayatının vazgeçilmez bir parçası olmuştur; (b) Romalılar hem devletin finansmanı hem de siyasi kararlar üzerine büyük etkisi olan toplusal sınıfların tamamı dahîl olmak üzere, savaştan ve toprakların genişlemesinden büyük karlar sağlamaktaydılar, savaşlarla ganimet ve kölelerin akışının yanında toprak sahipliğine dayalı refah artışının önü açılmaktaydı; (c) Roma senatosu bilinçli olarak açıktan yayılmacııık amacını beyan etmekteydi, bunun en temel dayanağı Roma'nın yapılan anlaşmaları fırsatını bulduğunda bozmasıydı; (d) Roma, resmi bir görüntü vermese de, genelde saldırgan bir niyetle hareket etmekteydi, yapılan savaşların saldırgan sebeplere dayanması bunun en önemli göstergesiydi. Bütün bu temel idialar içinde Roma emperyalizmiyle ilgili olarak üzerinde durulması gereken birincil unsurun sürekli savaşa dayalı ekonomik çıkar olgusu olduğunu düşünmekteyiz. Roma fethettikçe ekonomik gücünü artırmıştır. Savaşa dayalı bir ekonominin sürekliliği ve istikrarının temel şartı sürekli savaş kazanmaktan geçtiğinden Roma militarizmi güçlü ve acımasız kılınmıştır ${ }^{5}$. Aynı Roma, zaman zaman toprak ilhak etmeyi başaramamışsa, bunun sebebi ilgisiz veya isteksiz olduğundan değil, amaçlarına başka yöntemler aracılığıyla ulaşabildiğine inandığındandır. Uzaklık, lojistik, zorlu coğrafi şartlar ve düşmanın kaynakları gibi koşullar da dikkate alınmalıdır. Doğu, kentsel örgütlenme açısından daha gelişmiş, Batı ise kabile tarzı örgütlenmelere daha açık olduğundan, Roma'nın Yakındoğu'da yayılması birtakım coğrafi ve lojistik nedenlerden dolayı daha yavaş, aralıklı, ancak sürekli olmuştur 6 .

Harris'in görüşleri doğrultusunda Roma Cumhuriyet'inin kendine has saldırgan, savaşçı ve militarist bir aristokratik ruhla yönetildiğini ve bunun Roma hayat tarzının karakteristik bir özelliği olduğunu vurgulamamız gerekmektedir? ${ }^{7}$ Askeri başarı, sosyal statü ve politik güç birbiriyle

5 MÖ 168 yılında Makedonya ilhak edildiğinde gümüş madenlerinin kapatılması bu anlayışa ters gibi gözükse de, bunun özel bir sebebinin olması intimali yüksektir. Roma, büyük olasılıkla Makedonya ve İspanya gibi uzak ve tam anlamıyla kontrol altına alınamamış bölgelerde vergi toplama sistemini tam olarak oturtamamıştı. Bkz. Richardson $1976,139 \mathrm{vd}$.

Isaac 1990, 372.

Romalı aristokratların özellikle köle bazındaki talan ve gasp arzusu üretime de destek veren bir içeriğe sahiptir. Sürekli savaşlar olmadan ucuz köleler ve bireysel toprak sahibi oligarkların ellerine geçen yatırım parası olmayacaktır. Bu faktörleri birleştiren modelin analizi için bkz. Hopkins 1978, 59 vd. K. Hopkins de (Conquerors and Slaves, Cambridge University Press 1981, I. Bölüm) Roma toplumunun askeri tabiatına vurgu yapmış ve sürekli savaş yapmanın Cumhuriyetin son yirmi yılının sosyal ve ekonomik yapısının gereği olduğunu öne sürmüştür. $M$. Crawford (The Roman Republic, Harvard University Press 1993², 65 vd.) Roma saldırganlığını II. Makedonya Savaşı'nın sebebi olarak göstermeye çalışmıştır. Bazı bilim adamları ise Roma'nın her zaman saldırgan hareket ettiğine dair tek sebep üzerinde ısrarda bulunmasalar da, Harris'in "Saldırgan Emperyalizm" kavramını yapısal seviyede analiz ederek yeniden tanımlamış ve genişletmişlerdir. E. S. Gruen, The Hellenistic World and the Coming of Rome I-II (Berkeley/Los Angeles/London 1984) başlıklı eserinde bir nevi Harris'in görüşlerine destek vererek Romalıların Hellas anakarasına büyük oranda Hellenlerin sorunlarını giderme davetiyle çekildiğini ve Romalıların da tıpkı Klasik ve Erken Hellenistik Dönem Hellenleri gibi benzer mekanizmalarla bu bölgelerde kontrolü sağladıklarını savunmuştur. E. S. Gruen'in öğrencilerinden R. M. Kallet-Marx'ın Hegemony to Empire: The Development of the Roman Imperium in the East from 148 to 62 BC (Berkeley/Los Angeles/Oxford 1996) başlıklı eseri Doğu'da Roma müdahalesinin temellerini inceleyerek tartışmaları devam ettirmiştir. Kallet-Marx’ın eseri kronolojik kapsamda daha dar olsa da, olaylara yorumsal olarak daha geniş bakış açıları getirmiştir; buna göre hem Hellen hem de Roma tarafından karşılıklı uyuşmanın süreklilik arz eden süreci ve özel tarihi olaylara tepki bağlamında, ilgi emperyal 
sımsıkı etkileşim içinde olan değişkenler olmuştur. Roma aristokrasisi, özellikle senatörler çok güçlü bir askeri başarı ruhu ile büyütülmüş ve bunu özümsemişlerdir. Roma'da zaferin kendisi bile kurala bağlanarak en az beş bin düşman öldürülmesi şartı aranmıştır. Konsülün ve altındaki rütbelilerin savaşta kazandığı zaferler ve yaptığı fetihler onların yönetim mekanizması ve toplumda daha fazla statü ve otorite (auctoritas) kazanmalarının önünü açmıştır. Kazandıkları zaferlerden büyük bir kazançla dönen konsüller dikkat çekici gösteriş ve harcamalarıyla aristokrat veya elitler üzerindeki etkilerini koruyabilmiş ve statülerini yükseltebilmişlerdir. Senatörler normal şartlarda ana gelirleri olan toprakların işletilmesinden çok fazla bir birikim elde edemezken, kent mülklerinin kirasından, ticaret ve faiz gibi sektörlerden elde edilebilecek olan gelirler de riskliydi. Bu şartlar altında eyalet valilerinin yolsuzlukları ${ }^{8}$ veya savaşlardan daha düzenli ve doğrudan gelirler elde edilebilmekteydi. Senatodaki tartışmaların detayları tam olarak bilinmese de, kıskançlık ve savaşın gelirlerinden para kazanma hırsının başta konsüller olmak üzere Cumhuriyet Dönemi aristokratik liderlerinin sert rekabetine dayalı güçlü ve bilinçli bir yayılmacııık politikası benimsemelerine yol açtığı görülmektedir ${ }^{9}$. Roma aristokratları arasında MÖ II. yüzyılın ortalarına kadar savaşlardan nispeten daha dengeli bir kar elde etmeyi hedefleyen dayanışma ruhu, MÖ I. yüzyılda çökmeye başlamıştır. G. Marius ve P. C. Sulla dönemlerinde başlayan bu yöndeki rekabet ve sonucunda gelişen iç çatışmalar da M. L. Crassus, G. Pompeius Magnus ve G. I. Caesar arasında hız kazanarak devam etmiştir. Bunlara aynı yüzyılda özellikle Küçük Asia'da birbirine rakip olan hanedanların üst elit kesimi de eklenmiştir. Böylelikle geniş bir alana yayılan aristokratik rekabet, bütün Akdeniz coğrafyasında fetih girişimlerini tetiklemiştir. Bunu gerçekleştirecek olan Roma ordusu, kendi konumunu korumak ve refahını artırmak için gelirlerin veya vergilerin sürekliliğini sağlama bağlamında korku üreten bir kurum haline dönüştürülmüştür. Bu doğrultuda koruma şantajı stratejisi ile hareket etmiştir.

Roma, Cumhuriyetin kurulduğu MÖ 510/509 yılından itibaren sürekli savaşlara girişmiş ve bu savaşların çoğunu zamana yaymıştır. İtalya Yarımadası'ndaki yayılma sürecinde Latinlere karşı MÖ VII. yüzyıldan beri yürütülen uzun savaşlar sonucu MÖ 338 yılında nüfusu yoğun olan Latium bölgesini ele geçirmiştir. Bu süreçte Latin kentlerine ticari, ekonomik ve siyasi anlamda farklı farklı imtiyazlar vererek, yeri geldiğinde güçsüz olan Latin kentlerini güçlülere karşı destekleyerek birbirleriyle olan rekabet ve çatışmayı körüklemiş, böylelikle onları tek tek zayıflatmış ve üstünlüğünü nihayetinde kabul ettirmiştir. Bu arada Samnit dağ halklarına karşı yürütülen yine uzun

yapıların evrimine doğru çekilmektedir. Ayrıca bkz. Beard - Crawford 1985, 72-84; Cornell 1995, 345-68, özellikle 364-368.

8 Roma Cumhuriyet Dönemi siyasi ekonomisi kölelik dışında büyük oranda askeriye, memurlar ve güç hiyerarşisinde imtiyazlı pozisyonlar işgal edenlere yeniden dağıtılan düzenli haraç kesmelere dayanmıştır. Yöneticiler devam eden harcamalarını yerel elitlerin, vergi toplayıcılarının (publicani) ve benzerlerinin üzerine yıkmışlardır. Birinci Mithradates Savaşı'ndan (MÖ 89-85) sonra özellikle P. C. Sulla'nın Küçük Asya kentlerinden geriye dönük beş yıllık vergiyi toplanması ve diğer ağır şartları getirdiği görülmektedir. Kötüye giden ağır ekonomik koşullar L. L. Lucullus'un MÖ 71 yılındaki reformlarıyla düzeltilmeye çalışılsa da zaman zaman kentlerdeki ekonomik problemlerin devam ettiği görülmektedir (Plut. Luc. XX. 3-4; ayrıca bkz. Arslan 2007, 366 vdd.). Cicero (Att. V. 16.), MÖ 51 yılı itibarıyla Kilikia valisi iken muhtemelen abartılı olarak insanların kelle vergilerini ödeyemediklerine ve yatırımlarını sattıklarına dair ekonomik zorluklara işaret etmekle kalmayıp, tek bir kontratla vergi toplama ihalesi verilen Romalı publicani ve işbirlikçi yöneticilerin şiddet ve açgözlülüğünün, sorumsuzca aldıkları haraçların Roma yönetiminden egemenlik alanlarında nefret edilmesine yol açtığını bildirmektedir. Bkz. Brunt 1965, 269; Harrison 2008, 7-8, 10. Mylasalı hatip ve kentin en üst yetkilisi Hybreas, hâli hazırda iki yüz bin talanton vergi toplamış olan M. Antonius'un MÖ 41 yılında yılda iki kez vergi toplanması talebinde bulunduğunu, ancak bunun mümkün olmadığını belirtmektedir (Plut. Ant. XXIV. 5-6). G. I. C. Octavianus ve M. Antonius'a karşı savaşan M. I. Brutus ve G. Cassius Longinus, ilk kez kentlerden on yıllık vergiyi iki defada ödemelerini talep etmiştir (App. Bel. Civ. V. 1. 2; V. 3. 24). Sidebottom 2005, 320 vd. 
süreli savaşlardan sonra MÖ 282 yılında Orta İtalya'yı ele geçirmiştir. Bu savaşlarda Samnit dağ halkları ile başta Neapolis gibi Hellen koloni kent devletleri arasındaki özellikle toprak kullanımı anlaşmazlıklarından faydalandığı ve bu savaşlara müdahil olduğu görülmektedir. Roma daha sonra İtalya Yarımadası́nın diğer önemli gücü Tarentum'u yakınında Roma vatandaşlık hakkı verdiği bir koloni kurdurtarak tahrik etmiş ve savaşa zorlamıştır. Tarentum adına savaşan Epiruslu Pyyrhus, MÖ 275 yılında Beneventum Savaşı'nda yenilgiye uğratılmış ve bunun sonucunda MÖ 268 yılında Roma-italya Konfederasyonu kurulmuştur. Roma, bu noktaya gelinceye kadar İtalya Yarımadası'ndaki fethedilmiş halklardan öncelikli olarak asker talep etmiştir. Böylelikle gerektiğinde düşmanlarından daha fazla askeri sürekli olarak sahaya sürebilecek bir askeri güç haline dönüşmüştür. İkiyüz yıldan fazla bir süre ergin erkeklerinin yüzde onbeşini askeriyede tutmayı başarmış, gerekli eğitimleri de vererek sürdürülebilir bir savaş mekanizmasına sahip olmayı başarmıştır.

Roma, daha sonra İtalya Yarımadası'nın dışında Kartaca'yı gözüne kestirmiştir. MÖ II. yüzyılın ortalarında yazan ve Roma tarihi olayları hakkında daha sistematik bir anlatım tarzı ortaya koyabilen Polybios, hiçbir aklı başında insanın sadece düşmanını yenmek için savaşa girmeyeceğini, MÖ 264 yılında Birinci Kartaca Savaşı başlamadan önce konsüllerin niyetinde Kartaca'nın genişleme korkusundan ziyade talan güdüsünün yer edindiğine vurgu yapmıştır. Polybios, konsül P. C. Scipio'nun ağzından Roma'nın birinci Kartaca zaferinden itibaren dünya liderliği ve egemenliği doktrinini benimsediğini de beyan etmiştir ${ }^{10}$. Roma bu doktrin doğrultusunda İkinci Kartaca Savaşı sırasında madenleriyle zengin İspanya'daki Saguntum kentini Hannibal ve müttefiklerine karşı kışkırtmıştır. Saguntum'un Roma'dan cesaret alarak komşularına saldırma sebebinin iyi irdelenmesi gerekmektedir. Roma Birinci Kartaca Savaşı'ndan sonra Adriyatik Denizi'nin doğu kıyılarında Illyrium boyunca yerleşmiş olan korsanlara karşı mücadeleyi öne sürerek, Pharos Adası ile ilişkileri geliştirmiş ve yavaş yavaş bölgede üslenmeye başlamıştır. Hellen kentlerinde zengin tüccarlar, gemi imalatçıları ve büyük toprak sahibi, toprakların yeniden dağıtılmasına ve borçların ertelenmesine karşı çıkan elitlerle işbirliği içine girmiş ve talepleri doğrultusunda askeri müdahalede bulunmuştur. Müdahalenin başlangıç sebebini egemen olduğu bögelerde Makedonya kralı V. Philippos'a karşı nefrete ve ondan duyulan korkuya bağlamak çok sığ bir yaklaşım olarak karşımıza çıkmaktadır. Aslında Roma, V. Philippos'tan destek bekleyen egemenliği altındaki Hellen kentlerinde fakir halk kesimlerini ezme politikası gütmüş, MÖ 197 yılında gerçekleşen Kynoskephelai Muharebesi'nden sonra krala barış şartlarını kabul ettirmiştir. Roma'nın müdahalesinin başlangıç sebebini sadece Makedonya kralı V. Philippos'a karşı nefrete veya onun korkusuna bağlamak çok sığ bir yaklaşım olarak karşımıza çıkmaktadır. Bu arada Seleukos kralı III. Antiokhos'un Torosların ötesinden Thrakya içlerine kadar ilerleyen istila harekâtına göz yumarak, istila edilen bölgelere egemen olan bazı Hellen kent devletlerinin yanında Pergamon Krallığı ile Rhodosluları kendisinden yardım istemeye mecbur bırakmıştır. Onlarla ittifak yaparak III. Antiokhos'u MÖ 190 yılında Magnesia Muharebesi'nde yenilgiye uğratmayı başarmıştır. Roma'nın asıl hedefi bu zaferin nimetlerinden faydalanmak olmuştur. Savaştan hemen sonra Pamphylia ve Galatia içlerine düzenlenen seferlerle buralardaki kentlerden önemli ölçüde haraç toplanmıştır. MÖ 188 yılında yapılan Apameia Barış Anlaşması sonucunda da III. Antiokhos'tan da yüklü ölçüde savaş tazminatı alınmış, hatta kral Roma'ya verilen bu haraçtan dolayı maddi açıdan zor duruma düştüğünden MÖ 187 yılında Persia'da bir tapınağı talan ederek maddi kayıplarını

10 MÖ 202 yılında gerçekleşen Zama Muharebesi öncesinde bunu vurgulayan sözleri için bkz. Polyb. XV. 10. 2. MÖ 191 yılında Thermopylai Muharebesi öncesinde M. A. Glabrio'ya (Liv. XXXVI. 17. 15) ve MÖ 133 yılında T. Gracchus (Plut. Tib. Gracc. IX. 5; App. Bel. Civ. I. 1. 11)'a atfedilen benzer cümlelere bakınız. 
gidermeye çabalarken öldürülmüştür. Batı Anadolu bölgesi müttefik krallıklar Pergamon ve Rhodos arasında bölüştürülerek, onlar aracılığıyla Küçük Asya kentlerinden haraçlar toplanmaya devam edilmiştir.

Roma sonrasında Makedonya üzerinde tamamen egemenlik kurma arayışı içine girmiştir. MÖ 179 yılında V. Philippos'tan sonra tahta geçen en yaşlı oğlu Perseus'un Roma ile işbirliği yapan kent elitlerine karşı, reformcu sürgünlere, borçlardan kaçanlara sığınma hakkı verdiği ve Hellas boyunca yoksulların babası olarak anıldığı bilinmektedir. Ancak MÖ 168 yılındaki Pydna Muharebesi'nde ağır bir yenilgiye uğratılmıştır. Roma bölgedeki güçlü Makedonya Krallığı'nı parçalamış ve bölünen dört Cumhuriyetin vergi olarak topladıklarının yarısını talep etmiştir. Bu aşamada özellikle kontrolü altındaki Hellen kentlerindeki elit kesimleri piyon olarak kullanarak ekonomik çıkarlarını üst seviyelere taşımasını bilmiştir. MÖ 148 yılı itibarıyla, yukarıda da bahsettiğimiz üzere, Korinthos ve Thebai gibi kentlerde acımasız katliamlar yaparak Hellas'da da tam bir hâkimiyet elde ettikten sonra, Hellenlere imtiyazı davranma gereği duymamıştır. Roma, sadece bu kentlerdeki kısa süreli siyasi karmaşa dönemlerinde, birden fazla grup dış siyasi destek için birbiriyle rekabet ederken özellikle Roma vatandaşlığı başta olmak üzere kendi lehinde olanlara çeşitli imtiyazlar teklif etmiştir. Bunun dışında çok nadir de olsa, kentlerden hediyeleri geri çevirmiş, deprem ve afet gibi sebeplerden bazı kentlerin borçlarını ertelemiş veya affetmiş, önceden verilen imtiyazları tasdik etmiştir ${ }^{11}$. Dolayısıyla Roma'nın yardım yapılması veya imtiyaz bahşedilmesinde bile ihtiyatlı olduğu, çıkarları doğrultusunda hareket ettiği görülmektedir.

Diğer taraftan Roma, İkinci Kartaca Savaşı'ndan sonra İspanya, yani İber Yarımadası'nı da tamamen hâkimiyet altına almak için girişimlerini artırmıştır. İspanya'yı kontrol etmek ve buraya denizden daha fazla asker göndermek için Güney Fransa'yı da egemenlikleri altına almışlardır. Roma'nın saldırganlığı ve savaşları devam ettirme arzusunun en bariz örneği MÖ 149-146 yılları arasında gerçekleşen לु̈lincü Kartaca Savaşı olmuştur. Kartacalıların özellikle ticaretten elde ettikleri gelirlerle kendilerini toparlamaları onların uzun vadede sadece siyasi değil, ekonomik ve ticari açıdan da rakip konumlarını devam ettirebilecekleri anlamına gelmekteydi. Roma, bunun önüne geçmek için M. P. Cato'nun da sürekli senatoda ısrar ettiği üzere Kartaca'yı artık tamamen ortadan kaldırmaya karar vermiştir. Roma Kartaca'nın kabul ettiği üç yüz önde gelen vatandaşını esir olarak verme, bütün silahlarını teslim etme şartlarını yeterli bulmayarak kentin teslim edilmesi ve halkın on mil içeriye göç etmesi gibi ağır bir şart koşmuş ve onları savaşa mecbur kılmıştır. Roma'nın bu savaş sonrasında eski Kartaca topraklarındaki faaliyetlerini ve çıkarlarını artırdığı görülmektedir ${ }^{12}$. Kartaca ortadan kaldırıldıktan sonra Roma yine akıllı bir siyasetle Pergamon kralı III. Attalos ile ikili diyaloğu sayesinde onun vasiyetiyle Pergamon Krallığı'nı MÖ 133 yılında şüpheli bir veraset? yoluyla devralmayı başarmı ${ }^{13}$ ve buna karşı çıkan Aristonikos liderliğindeki halk ve köle ayaklanması MÖ 129 yılında sert bir şekilde bastırılmış ve provincia Asia kurulmuştur. Roma daha sonra Numidia Krallığı'nda yatırım ve ticaret yapan Romalı işadamlarının kışkırtması sonucu MÖ 112 yıında bu krallığa savaş açmış ve bu savaş altı yıl sürmüştür. Küçük Asya'da ise Romalı işadamları ve vergi memurlarının istismarları MÖ 88 yııı itibarıyla öyle bir boyuta ulaşmıştır ki, Karadeniz kralı VI. Mithradates Anadolu halkından büyük bir destek alarak çoğu işadamı seksen bin civarında Italia kökenli insanı ve Roma vatandaşını katletmiştir ${ }^{14}$. Bunun üzerine P. C. Sulla ve sonrasında G. Pompeius Magnus, Roma iç savaşının kızıştığı bir

11 Dimitriev 2000, 452-3.

12 Hobson 2016.

13 Bu vasiyetin Roma tarafından uydurulması konusunda bkz. Sall. Hist. IV.67.8; ayrıca Demir 2011, 184.

14 Katliamının nedenleri ve sonuçlarına ilişkin olarak ayrıca bk. Arslan 2007, 159 vdd. 
dönemde Anadolu'nun en güçlüsü Pontos ve müttefiki Armenia krallarına karşı MÖ 88 yılından MÖ 63 yılına kadar uzun süreli savaşmış ve nihayetinde Pontos-Bithynia ve Kilikia eyaletleri kurulmuştur. Bu süreçte özellikle P. C. Sulla'nın Küçük Asia'daki kentlerden çok ağır vergiler ve haraçlar topladığı bilinmektedir. G. Pompeius Magnus Suriyedeki Seleukos Hanedanlığı egemenliğine son vererek Suriye-Filistin sahillerini de içine alan bir provincia kurulmuş ve buradaki kentler de haraca bağlanmıştır. Bu arada Roma, Karadeniz Krallığı'nın tehdidini kullanarak Bithynia kralı IV. Nikomedes'i türlü sözlerle kandırmış ve onun MÖ 74 yılında krallığını Roma'ya veraset yoluyla devretmesini sağlamıştır. Hatta Roma yine durmamış, aşağıda bahsedeceğimiz üzere bu sefer Crassus'un liderliğinde Parthlara saldırmaya karar vermiş, ancak MÖ 53 yılında ağır bir yenilgiye uğratılmıştır. Roma, Anadolu'daki egemenlik sürecinde Hellas'ta olduğu gibi kendisi ile birlikte hareket eden üst elit kesime her türlü desteği vermiştir ${ }^{15}$. Doğu Anadolu'nun askeri lojistik açısından zorlandıkları bölgelerini tamamen işgal ederek eyalete dönüştürmek yerine, Armenia, Kappadokia gibi kralıklar aracılığı ile kontrol altında tutmaya çalışmıştır. Bu krallar Roma ile birlikte hareket ettikleri sürece Romalı sermayedarlar buralara rağbet etmiş, publicanus 'lerin denetiminde Roma vatandaşları adına toprak ilhakları gerçekleşmiştir.

Roma, Doğu'da Parthlar karşııında aldığı başarısızlığın üzerine dikkatini Mısır'da ilerlemiş bir tarım ve ticaret ekonomisini yöneten Ptolemaios Hanedanlığı krallarına çevirmiştir. G. Pompeius Magnus, MÖ 48 yılında G. I. Caesar'a karşı Pharsalus Muharebesi'nde yenildikten sonra Mııır'a kaçmıştır. Ancak burada XIII. Ptolemaios'un emirleri doğrultusunda suikaste kurban gitmiştir. G. Pompeius Magnus'un peşinden Mısır'a gelen G. I. Caesar'ın bunu hoş karşılamadığı, bahane etmeyi tercih ettiği, nihayetinde kralla çatışmaya girerek onu öldürttüğü ve babasının yerine sevgilisi VII. Kleopatra'yı tahta çıkartarak hanedanlığı ekonomik açıdan sömürüye elverişli neredeyse vasal bir krallığa dönüştürdüğü görülmektedir. G. I. Caesar, Mısır'dan dönüş yolunda da son Karadeniz kralı II. Pharnakes'i Zela (Tokat-Zile) Savaşı'nda MÖ 47 yılında yenilgiye uğratmıştır. Roma'nın bu bitmek bilmeyen saldırgan savaşlarına ancak MÖ 31 yılında G. I. C. Octavianus ile M. Antonius/VII. Kleopatra ittifakı arasında gerçekleşen Actium Deniz Muharebesi'nden sonra ara verilecektir. G. I. C. Octavianus'un Actium zaferi, Roma'nın Mare Nostrum (bizim deniz, yani Roma Akdeniz'i) üzerinde tek başına tartışmasız egemenlik kurmasına yol açmış ve Pax Romana dönemi başlamıştır. Sonuçta özellikle MÖ II. yüzyılın ikinci yarısından itibaren Roma Cumhuriyeti'ne yön veren ve aynı zamanda birbirleriyle rekabet içinde olan liderlerinin önderliğinde gerçekleşen savaşların Augustus unvanını alan G. I. C. Octavianus'un kurduğu principatus dönemine kadar aralıksız devam ettiği görülmektedir. Yukarıda girişte verdiğimiz metinde de vurgulandığı üzere, Augustus sonrası dönemde MÖ I. yüzyılın ilk çeyreğinden itibaren emperyal yayılmacı siyasete devam edilmiştir.

Roma'nın Cumhuriyet Dönemi'ndeki bu sürekli savaşa dayalı, yayılmacı emperyalist siyasetiyle ilgili olarak Yakındoğu'dan iki örnek konu üzerinde durabiliriz. Birincisi Roma'nın askeri operasyonları sırasında korsanlığı bastırmada ne kadar samimi olduğu meselesidir. Roma, MÖ ı. yüzyıl başlarından itibaren özellikle Kilikia'da yuvalanan korsanların artan yıkıcı faaliyetleri sonucunda Küçük Asia'nın güney sahillerine daha fazla ilgi göstermeye başlamıştır. Roma senatosu, triumvir M. Antonius'un aynı isimle bilinen büyükbabası prokonsül M. Antonius, MÖ 103 yılında muhtemelen emrindeki küçük bir Roma askeri gücüyle Pamphylia'da Side kentine gönderilmiş ve buradan operasyonlarını yönetmeye başlamışıı ${ }^{16}$. O, bu görevi sırasında MÖ 101/100 yılında Lex

15 Dimitriev 2000, 454.

16 De Souza 1999, 105. Side'ye gittiğini teyit eden yazıtla (CIL $1^{2} .2662=$ ILLRP 1. 342) ilgili yayın için bkz. Taylor West 1928, 9-22. 
de Provincii Praetoriis (Korsanlara Karşı Kanun)'in çıkartılmasına öncülük etmiştir ${ }^{17}$. Roma'daki konsül bu kanundaki şartlar doğrultusunda Doğu'nun bağımsız kent devletlerine, Mısır, Suriye, Kirene ve Kıbrıs'ta hüküm süren krallara, yani Doğu Akdeniz'in kıyılarına hükmeden bütün yönetimlere mektup göndermiştir. Mektuptaki talimatlara göre; bu yöneticiler ve askerleri hakimiyet alanlarında herhangi bir korsanın yelken açmasına ve limanlarına girmesine asla müsaade etmeyecekler, Roma vatandaşları ve Italialıların işleriyle gerektiği gibi ilgilenecekler, Roma'nın müttefikleri egemenlik alanlarındaki denizlerde işlerini düzgün bir şekilde yürütebilecek ve yelken açabileceklerdir. Diğer taraftan bu kanunun uygulamadaki sonuçlarını ortaya koyabilecek pek fazla bir delil bulunmamaktadır. Roma, Küçük Asia'nın doğusunda korsanlığın kontrol edilmesiyle ilgili girişimlerinde büyük oranda yerel deniz güçleri ve özellikle Rhodos ve Lykia kentleri gibi bağımsız yönetimlerden faydalanma yoluna gitmiştir ${ }^{18}$. M. Antonius da çok geçmeden Roma'ya geri dönerek MÖ 99 yılı için konsül seçilmiştir.

Aslında Roma'nın, uygulamada sıkıntılar yaşayacağını bildiği halde, bu kanun bildirgesini tek tek Doğu Akdeniz'deki her yönetime göndermesinin ve dost olmaya devam etmek isteyen herkesi kendisine katılmaya davet etmesinin asıl sebebinin bir nevi nabız yoklamak olduğu kanaatindeyiz. Böylelikle Doğu Akdeniz çevresindeki denizlerde egemen olan yönetimlerden gereğini yapmayanlar açıkça ya korsan ya da korsanların destekçileri olarak ilan edilecekti. Yaymak istedikleri mesaj açıktır, 'ya bize katılırsınız ya da korsan olarak mimlenerek müsbet askeri hedefimiz haline gelirsiniz'. Dolasıyla Roma, korsanlıkla mücadele yasası altında, özellikle Pamphylia ve Kilikia gibi ele geçirmesi zor olan bölgelerde kendileriyle birlikte hareket etmeyen ve de boyun eğmeyenleri 'düşman hedef' olarak gösterebilecekti. Böylelikle aslında emperyalist, sömürüye dayalı olan amaç meşrulaştırılmaya çalışılmaktaydı. Yakın geçmişteki araştırmalar Pamphylia ve Kilikia gibi bölgelerin yeraltı ve yerüstü kaynakları sayesinde gelişmiş ve oldukça müreffeh olduğunu; üzüm, tatlı şarap, kereste ürettiğini ve köleler sağladığını ve bu sayede Doğu Akdeniz ekonomisinde önemli rol oynadığını göstermektedir.

Roma, ilgili kanunun geçmesinden sonra başta Syedralılarla birlikte Kilicia, Pamphylia ve Lykia bölgelerinde hızla ilerleyeceği beklentisi içine girmiştir, ${ }^{19}$ ancak yine de tam anlamıyla bir müdahalede bulunamamıştır. Diğer taraftan Roma, kendisine karşı Kilikialı korsanlarla işbirliği yapan Karadeniz kralı VI. Mithradates ve $Q$. Sertorius gibi yöneticileri cezalandırılmayı hak eden düşmanlar olarak sergileme gayreti içine girerek kendisine olan müttefik desteğini artırma stratejisi izlemiştir $^{20}$. Bu strateji doğrultusunda, tahammüllerin de ötesinde, kendisiyle ittifak kurmaya yanaşmayan bölgesel rakiplerine karşı zaman zaman korsanlık veya haydutluk tehdidini kullandığı ve onlara karşı korsanlık faaliyetlerini el altından desteklediği çıkarımında bile bulunabiliriz. Dolayısıyla Roma, askerlerine, parasına ve diğer kaynaklarına ihtiyaç duyduğu kıyı kentleri ve kasabalarının mülkleri ve halkı üzerine belli dönemlerde korsan veya haydut saldırılarına göz yumarak havayı bulanıklaştırmış, böylelikle onları kendi egemenlik bölgelerinde yeniden güvenliğin ve istikrarın

17 Metnin tamamı, tercümesi ve yorumu için bkz. Crawford 1996, 231-270.

18 Beek 2015, 109.

19 Syedra kenti büyük olasılıkla bu kanunun talepleri doğrultusunda bir kehanet tavsiyesine uyarak korsanlara karşı Roma'nın yanında durduğunu göstermiştir. Benzer şekilde Ksanthos'tan gelen MÖ I. yüzyıl başları veya MÖ II. yüzyıl sonlarına tarihlendirilen yazıtlarda Aikhmon liderliğindeki bazı Lycia kentlerinin korsanlara karşı mücadelesine değinilmektedir. Bkz. De Souza 1997, 480-481; Arslan 2002, 115 vdd.

20 Özellikle VI. Mithradates korsanların ve haydutların dostu olarak gösterilmektedir (App. Mith. IX. 63; XIV. 92). VI. Mithradates-Roma Savaşları'nın Kilikia'da korsan ve haydutlara cesaret vermesi hakkında ayrıca bkz. Flor. III.6.1-2. Roma'ya karşı savaşmak için korsan paralı askerler kiralaması hakkında bkz. Plut. Luc. XIII.3. Diğer taraftan Roma'nın VI. Mithradates'e karşı yürütülen savaş esnasındaki tamahkâr talanları hakkında bkz. Plut. Luc. XVII.5-6. 


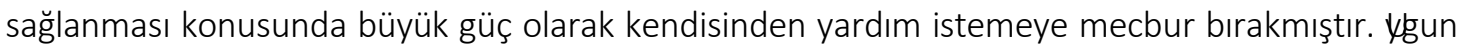
gördüğü yer ve zamanlarda da korsanlara karşı gerekli yardımı yapmış, böylelikle yardımda bulunduğu kent ve kasabaları kendisinin müttefiki yapmakla kalmamış, korsanlığı bastırdığı havası oluşturarak Doğu Akdeniz dünyasında hayırsever bir devlet imajı oluşturmak istemiştir.

Daha sonra P. C. Sulla, MÖ 95 yılında lex de provinciis praetoris yasası kapsamında praetor olarak atanarak başta Kilikia olmak üzere Anadolu'nun güney sahillerini korsanlardan temizleme görevini üstlenmiştir, ancak kendisi yolda iken kral Ariobarzanes'i yeniden tahtına oturtmak için Kappadokia'ya gitmek zorunda kalmıştır ${ }^{21}$. Aşağıda da açıklayacağımız üzere P. C. Sulla'nın hedefinde MÖ 95/4 yılından itibaren aktif olarak Doğu Lycia'da Olympos kentinde kendisini kral ilan ederek korsanlık faaliyetlerine girişen Zeniketes olmalıdır. Roma'nın sadece neredeyse iki yıl sonra MÖ 92 yılında Kilikialı korsanlara karşı detayları bilinmeyen bir harekatta bulunduğu bilinmektedir. Daha sonra MÖ 88 yılında Birinci Mithradates-Roma Savaşı patlak vermiştir. Korsanlar VI. Mithradates'in saldırılarının yol açtığı istikrarsızlıktan faydalanarak Anadolu'nun güney sahillerindeki saldırılarını artırmaya başlamışlardır. Roma, bu süreçte de korsanların üzerine gidilmesi işine öncelik vermemiştir. MÖ 85 yılına kadar ilgili korsanlık faaliyetlerine karşı herhangi bir girişimde bulunulduğuna dair bir delil yoktur. Sadece P. C. Sulla, MÖ 85 veya MÖ 84 yılında korsanlara karşı bir donanma oluşturması talimatıyla Asia'daki görevini Murena'ya devretmiş̧ir ${ }^{22}$. Görevi devralan Murena, Lykia içlerine kadar ilerlemiş, Kibyra'nın yöneticisi Moagetes'e saldırmış ve aynı zamanda Bubon, Balbura kasabalarını ele geçirmiştir ${ }^{23}$. Appianos, ne Murena'nın ne de ondan sonra P. S. Vatia Isauricus'un korsanlara karşı kaydedeğer bir başarı gösteremediğini bildirmektedir ${ }^{24}$. Daha sonra yine Kappadokia Bölgesi'ne yönelmiş ve burada bir takım başarılar elde etse de P. C. Sulla tarafından çok geçmeden geriye çağrıımışıır ${ }^{25}$.

Roma, Zeniketes'in Lycia bölgesi başta olmak üzere korsanlık faaliyetlerini yoğunlaştırdığı dört yıl aradan sonra harekete geçmeye karar vermiştir. ${ }^{26}$ Cicero, prokonsül G. C. Dolabella'nın MÖ 80-79 yıllarında Pamphylia ve Kilikia bölgelerindeki operasyonlarına değinmektedir. Bu sırada Cicero'nun baş düşmanı G. Verres ise G. C. Dolabella'nın legatus proquaestoresi idi. G. C. Dolabella'nın yetki alanının özellikle Lykia, Milyas, Pamphylia, Pisidia ve Phrygia bölgeleri olduğuna vurgu yapılmaktadır. Önceliği Pamphylia'daki korsan üslerini ortadan kaldırmak olacaktır. Oysa ki ne gibi askeri harekatlarda bulunduğu tam anlamıyla detaylandırılamamaktadır ${ }^{27}$. Diğer taraftan korsanlığı yok etme bahanesi altında kendisinin de bir nevi korsanlık faaliyetlerinde bulunduğu anlaşılmaktadır. Onun ve özellikle G. Verres'in Lykia, Pamphylia ve Kilikia Trakheia topraklarında sözde korsanlara karşı mücadele teşebbüsleri altında sahillerdeki pek çok kenti ve tapınağı talan etmesi, bölgedeki halkın Romalılardan nefret etmesine sebep olmuştur. Aspendos'ta çalınmadık tek bir güzel heykel bile bırakmadığı, Perge'deki Artemis Tapınağı'nın bütün altınlarını gasp ettiği bildirilmektedir ${ }^{28}$. Bütün bu gelişmeler G. C. Dolabella'nın da aslında korsanlığı bastır-

21 Plut. Sull. V; ayrica bk. Arslan 2003, 95.

22 Appianus (Mith. IX. 64), kısaca Murena'dan iki lejyonla Asya'yı kontrol altında tutmasının beklendiğini bildirmektedir. Cicero (Verr. II. 1. 86-89), bu donanmanın korsanlara karşı bir maksadı olduğunu önermektedir. Bu dönemde Murena'nın Asya'daki görevi hakkında bkz. De Souza 1999, 121-4.

23 Murena'nın askeri operasyonları hakkında bkz. Cic. Verr. II. 1. 89; Strab. XIII. 4. 17; App. Mith. IX. 64; XIV. 93; Ps.Aur. Vic. De Vir. II. LXXIV. 2.

24 App. Mith. XIV. 93.

25 Reardon 1997, 185-186.

26 Zeniketes'in MÖ 94-79 yılları arasına denk gelen korsanlık faaliyetleri hakkında bkz. Arslan 2003, 96.

27 G. C. Dolabella'nın donanmasının Lykia, Pamphylia, Rhodos ve Kilikialılardan oluştuğu bildirilmektedir (App. Bel.Civ. IV. 8. 60).

28 Detaylar için bkz. Cic. Verr. I. 11; II. 1. 41-102; II. 2. 109; II. 3. 177. Cicero'nun bu söylevi üzerine Asconius ve Ps.- 
mayı umursamadığını gözler önüne sermektedir. Tam tersine böylesine olumsuz tavırlar yüzünden bölgedeki Roma publicanuslarının zulmünden ve baskısından kaçanlar da korsanlara sığınmış ve hatta korsan olmaya teşvik edilmişlerdir. Korsanlar gasp ettikleri malları savaş ganimeti olarak benimsemeye başlamışlar ve korsanlık hırsızlık olarak değil, Roma'ya karşı şan, şöhret ve servet biriktirme aracı olarak kabul görmüştür ${ }^{29}$.

Daha sonra P. S. Vatia Isauricus'un MÖ 78-74 yılları arasında dört yıl süren seferi sonucunda korsanlara karşı belli bir başarı elde edilebilmiştir. Sallustius ve Livius'un tarih eserlerinin ilgili kısımları günümüze kadar ulaşamadığından, P. S. Vatia Isauricus'un ilgili seferlerinin detayları hakkında pek fazla bir bilgiye sahip değiliz. Herşeye rağmen P. S. Vatia Servilius'un seferleri yirmi yıl aradan sonra korsanlar karşısında elde edilen en ciddi başarı olarak kendisini göstermektedir. P. S. Vatia Isauricus, batıdan doğuya doğru sırasıyla Phaselis, Olympos, Doğu Lykia'daki Korykos kentlerini öncelikle ele geçirmiştir ${ }^{30}$. Zeniketes'in merkez kalesi Korykos ele geçirildiğinde onun eviyle birlikte ateşe verildiği bildirilmektedir ${ }^{31}$. P. S. Vatia Isauricus, daha sonra Pamphylia içlerine kadar ilerlemiş, burada Attaleia gibi ZeniKetes'i destekleyen yerleşimlerden toprak ele geçirmiştir ${ }^{32}$. Ancak Strabon, Pamphylia'da Sidelilerin, belki kendileri de korsanlıkla uğraştıklarından, kentlerinin liman ve agoralarında korsanların ganimetlerini pazarlamasına ve tersanelerini kullanmalarına izin verdiğini bildirmesine rağmen ${ }^{33}$, P. S. Vatia Isauricus'un Sidelileri cezalandırmaması düşündürücüdür. Florus, onun sonrasında çetelerin kol gezdiği Isauria Bölgesi'nin dışında korsanların Kilikia'daki kalelerini de "yağmaladığını" öne sürmektedir ${ }^{34}$. Bunun yanında Florus, korsanlara karşı mücadele adı altında genelde kentlere yönelik talana ve aynı zamanda bölgede yeterince güç veya askeri garnizon bırakılmadı̆ı̆ndan korsan faaliyetlerinin devam ettiğine vurgu yapmaktadır ${ }^{35}$.

Diğer taraftan Florus'un bu iddialarına rağmen, P. S. Vatia Isauricus'un ne Kilikia kıyılarında ne de Kilikia Trakheia bölgesinde korsanlara karşı sefer düzenlemediği öne sürülmektedir ${ }^{36}$. Merkez korsan üssü olan ve Küçük Asya içleriyle karadan da yol güvenliğinin sağlanması açısından stratejik bir konuma sahip olan bu bölgelerde askeri operasyonlarını devam ettirmemesi ilginçtir. Bu P. S. Vatia Isauricus'un Anadolu'nun güney sahillerinin tamamında korsanlığı bitirmeden geri döndüğü anlamına gelmektedir. Roma'ya geri dönüş yolu üzerinde de zincire vurulmuş, damgalanmış korsanlar ve haydutları dostları ve müttefiklerine bilinçli olarak teşhir etmiştir ${ }^{37}$. Bölgedeki yöneticiler ve halk önünde böylesine bir nümayişte bulunarak seferinin meşru olduğu imajını vermeye çalışmıştır. Aslında büyük ihtimalle kendi siyasi çıkarları doğrultusunda istediği bölgelerde karmaşa yaratmak için belli bir süre göz yumduğu ve kullandığı korsanları, işi bitince şimdi gerçek düşmanıymış gibi göstererek prim elde etmeye çalışmaktadır.

Özetle P. C. Sulla, G. C. Dolabella ve P. S. Vatia Isauricus'un seferleri korsanları tamamen

Asconius'un yorumlarıyla ilgili ve diğer kaynak referansları için bkz. Reardon 1997, 186 dn. 255.

29

Arslan 2003, 100.

30 Cic. Agr. II. 50; Verr. II. 1. 21; II. 4. 22; Liv. perioch. XC; Flor. I. 41. 3-5; Strab. XIV. 5. 7; Eutr. VI. 3; Oros. V. 23.22; Vell. Pat. II. 39. 2; Amm. Marc. XIV. 8. 4. Konuyla ilgili ayrıca Sallustius'un fragmanlarına ve Ps.-Asconius'un eserine atıflar için bkz. Reardon 1997, 186 dn. 259.

31 Strab. XIV.5.7.

32 Agr. I. 5; II. 50.

33 Bu konuda bkz. Arslan 2003, 102

34 Flor. I. 41. 5. Isauria bölgesinde Isaura Vetus ve Isaura Nova yerleşimleri ele geçirilmiştir (Reardon 1997, 187).

35 Flor. I. 41. 5-6.

36 Reardon 1997, 187

37 Cic. Verr. V. 66. 
ortadan kaldırmada başarılı olamamıştır. Daha sonra G. Pompeius Magnus'un bu kişiliklerden daha fazla istirmarcı olduğu, korsanlığı bastırma bahanesiyle gerçekte emperyalist amaçlı seferler düzenlediği bildirilmektedir ${ }^{38}$. Tribün Aulus Gabinius'un gayretleriyle MÖ 67 yılında bir yasa çıkartılarak G. Pompeius Magnus'a denizleri korsanlardan temizleme görevi verilmiş ve bunun için kendisine çok miktarda asker, para ve gemi tahsis edilmiştir. G. Pompeius Magnus, bu yasa sayesinde Roma'da askerler, senatörler, önde gelen magistratlar ve Roma dışındaki müttefikler üzerinde istisnai bir imperium yetkisine sahip olmuştur. Onun destekçileri bu yasanın çıkmasında, kentin yiyecek ihtiyacının sekteye uğraması yönündeki tehdit, ticaretine verilebilecek zarar ve korsanlara karşı Roma çıkarlarını öne sürerek önde gelen etkili senatörlerin, equester sınıfının ve halkın desteğini almayı başarmıştır ${ }^{39}$. Aslında korsanların Roma'da yiyecek kıtlığına yol açacak kadar Doğu Akdeniz ticaretine darbe vurdukları ve hatta İtalya Yarımadası'nı bile yağmalayabilecekleri meselesi tartışmaya açıktır. Bu durum G. Pompeius Magnus'a çok güçlü yetki veren ilgili kanunu çıkarmak için abartılmış gerekçeler kapsamında, iç siyasetin yönlendirmesi olarak değerlendirilebilir. Sonuçta G. Pompeius Magnus, bu yasa sayesinde olağanüstü yetkilere kavuşmuştur.

G. Pompeius Magnus'un, özellikle MÖ 75 yılından sonra neredeyse bütün Akdeniz'e bir yara gibi yayıldığı iddia edilen korsan faaliyetlerini, Pamphylia ve Kilikia gibi zorlu bir bölge de dahil, MÖ 67 yılından sonra kırk ila doksan gün arası gibi kısa bir süre içinde çok fazla kaynak tüketmeden kontrol altına alması, aslında korsanlık tehdidinin abartılmış olabileceği düşüncemizi desteklemektedir ${ }^{40}$. G. Pompeius Magnus'un, kamuoyunda büyük korku unsuru olarak gösterilen korsanları bu kısa sürede önce Italia etrafındaki denizlerden temizlediği ve güvenliği sağladığı, sonrasında baş hedef durumundaki Pamphylia'yı fethettiği ve Kilikia'daki kaleleri Coracesion önlerinde korsanları yenilgiye uğrattığı, sözde korsan liderlerinin teslim olmasını sağladığı bildirilmektedir. Onun bu mücadele sırasında sonuna kadar savaş ve zorlu kuşatmalarla teslim olmaya zorlama yöntemi yerine, her aşamada düşmana genel affa dayalı derhal teslim olunması ve barış sağlanması teklifinde bulunması ve bunda sonuç alması da şüphelidir ${ }^{41}$.

Bu konudaki şüphelerimizi artıran durumlardan birisi de G. Pompeius Magnus'un tutsak alınan bu sözde korsanlarla ilgili yumuşak tavrıdır. G. Pompeius Magnus, MÖ 62 yılı sonlarında Roma'ya geri dönmüş ve senatodan MÖ 28-29 Eylül 61 tarihinde Roma'da bir zafer şöleni düzenleme izni almıştır. Onun MÖ 67 yılında yaklaşık 40 gün gibi bir süre zafında korsanların tamamını temizlediğini kabul edecek olursak, tutsak alınan korsanların yaklaşık altı yıl boyunca nerede hapiste tutulmuş olabileceği sorusu aklımıza gelmektedir. Nitekim bu hapiste tutulan korsanlar zafer şöleni yürüyüşünde halkı coşturmak için sergilenmiştir. Ancak Plutarkhos anlatımında G. Pompeius Magnus tarafından esir alınan önemli liderlerin listesini verirken sadece sergilenen korsanlar olduğunu bildirmekte, onların ne liderlerinin isimlerinden ne de öneminden bahsetmektedir ${ }^{42}$. Appianus da isimlerini vermeden sadece yerel elbiseler giydirilmiş ve kalabalık

38 Plut. Pomp. II.

39 Plut. Pomp. XXV. 1.

40 Cic. Man. XXXV: Pompeius, Brundusium'dan sefere çıktıktan sonra kırk dokuz gün içinde Kilikia'nın tamamını ele geçirdi ve MÖ 67 yılı baharın başından yaz ortalarına kadar korsanlara karşı savaşı sona erdirdi; Liv. perioch. XCIX: kırk gün içinde denizler temizlendi ve onlara Kilikia'da boyun eğdirilerek savaş sona erdi; Vell. Pat. II. 32. 4: Pompeius kısa sürede savaşı bitirdi; Plut. Pomp. XXVI: Batı denizleri kırk günde, bütün denizler üç ayda korsanlardan temizlendi; Flor. I. 41. 15: hepsi kırk günde temizlendi; Eutr. VI. 12: birkaç ayda temizlendi; Ps.-Aur. Vic. De Vir. II. LXXVII. 5: kırk gün içinde temizlendiler (Mox piratas intra quadragesimum diem subegit).

41 G. Pompeius Magnus'un iç siyasi kariyerini ilerletmede korsanlık tehdidini kullanması konusundaki tartışma için bkz. De Souza, 2008, 83-84.

42 Plut. Pomp. XLV. 4. 
ancak zincire vurulmamıs bir tutsak ve korsan grubunun sergilendiğini aktarmaktadır. Diğer tutsak alınan önemli liderlerin ise isimlerini vermekte ve onların halk üzerinde daha fazla etkili olduğunu vurgulamaktadır. Asıl ilginç olan nokta Aristobulos ve Genç Tigranes dışında bu mahkumların idam edilmemesi ve hatta G. Pompeius Magnus'un "kamu zararına" da olsa kralların dışında korsanlar da dahil bütün esirleri evlerine göndermiş olmasıdır ${ }^{43}$. Roma kanunlarında normal şartlarda böyle bir af uygulaması bulunmamaktadır ${ }^{44}$. Bu da aklımızda yürüyüşte sergilenenlerin sözde korsan esirler olabileceği şüphesi uyandırmaktadır. Kanaatimizce Roma, sözde korsanlık probleminin Pamphylia ve Kilikia'da dahil geniş bir coğrafyada kentler ve topluluklar üzerine baskı oluşturmasına göz yumarak, hedef bölgelerdeki kentleri kendisine muhtaç ve bağımlı duruma düşürmek istemiştir ve böylelikle müdahalenin yolunu açmıştır. Kısaca Roma, istediği bölgelerde istediği zaman korsanlığı kullanarak hem kundakçı hem de itfaiyeci rolünü kendisine biçmiş, çıkarlarını ileri seviyelere taşımasını bilmiş̧ir.

Roma'nın gereksiz yere sürekli savaş çığırtkanlığı yapması ve emperyalist çıkarları doğrultusunda savaşa girmesi örneğini sanırım en iyi şekilde konsül M. L. Crassus'un Doğu seferi ve Carrhae Muharebesi örneğinde bulabiliriz. Bu konuya kısaca değinmek gerekirse; MÖ 60 yılında senatonun gücüne karşı Roma'nın önde gelen üç lideri, M. L. Crassus, G. Pompeius Magnus ve G. I. Caesar kendi aralarında I. Triumvirlik yönetimini kurmuşlardır. Hırslı bir aristokrat olan M. L. Crassus, köle eğiticisi olarak büyük paralar kazanmakla kalmayıp, P. C. Sulla diktatörlüğünün kurbanlarından ucuz topraklar satın alarak ve bunları daha sonra büyük karlar karşılığında satarak büyük bir servet biriktirmişti. Aynı zamanda politik hırsları olan genç aristokratlara para ödünç vererek siyasi konumunu daha da güçlendirmişti. Hatta onun bir itfaiye teşkilatına sahip olduğu, yangın mahalline ulaşarak, yangını söndürmeden önce karar kılınan bir fiyatla mülkü satın alacak kadar gözünü para hırsı bürüdüğü iddia edilmektedir. O, daha sonra MÖ 73 yılında Spartacus liderliğinde başlayan köle ayaklanmasını bastırarak itibarını artırmıştır. Diğer taraftan G. Pompeius Magnus, yukarıda bahsettiğimiz korsanlar karşısında başarı elde etmekle kalmayıp, Doğu'da VI. Mithradates ve Armenia kralı II. Tigranes'in kralıılarını da boyunduruk altına almayı başarmış, Roma'nın gücünü Syria ve ludaia'ya kadar genişletme başarısı göstermiştir. O, böylelikle itibarını M. L. Crassus'unkinin de ötesine taşımıştır. M. L. Crassus'un maddi desteğiyle Roma'da gladyatör yarışmalarını da içeren halk eğlenceleri düzenleyerek popüler olan G. I. Caesar ise, MÖ 57 yılında beş yıllığına vali olarak atandığı Gallia Cisalpina ve Transalpina'daki 50 civarındaki kabileye karşı yürüttüğü askeri başarıları sayesinde ününe ün katmıştır.

M. L. Crassus, bu iki liderin son dönemlerdeki başarıları karşısında Roma'daki nüfuzunun azalmakta olduğunun farkındaydı. Plutarkhos'a göre M. L. Crassus, bu aşamada tıpkı G. I. Caesar ve ve G. Pompeius Magnus'unki gibi itibar elde ederse, Roma'da tekrar en nüfuzlu lider olabileceğini düşünmekteydi ${ }^{45}$. Roma'da itibar kazanmanın yolu ise zafer kazanmaktan geçmekteydi. O, Doğu'da G. Pompeius Magnus'un bile cesaret edemediği Parthlara karşı bir zaferle bunu gerçekleştirebilirdi. Bu doğrultuda senatonun onayladığı Lex Trebonia yasası içinde M. L. Crassus'a "Suriye ve komşu topraklarını beş yıllığına yönetmesi, vatandaş ve müttefik askerlerin tamamını kullanarak kiminle isterse savaş yapabilmesi" yetkisi verilmiştir ${ }^{46}$. Livius ve Plutarkhos ise ona açıkça Syria'da ve Parthlara karşı sefer yetkisinin verildiğini bildirmektedir ${ }^{47}$. Diğer taraftan

43 App. Mith. XVII. 116-117.

44 Reardon 1997, $98 \mathrm{vd}$.

45 Plut. Cras. XII. 1; XIV. 4.

46 Cass. Dio XXXIX. 33. 2; XL. 12. 1.

47 Liv. perioch. CV; Pomp. LII. 3. Velleius Paterculus (II. 46. 2), "Suriye'nin hala kafasında bir Parth savaşı kurgulayan 
Plutarkhos bir diğer biyografi çalışmasında, çıkarılan kanunda özel olarak bir Parth savaşından bahsedilmediğine vurgu yaparak kendi içinde tezata düşmektedir ${ }^{48}$. Plutarkhos, belki de savaşın kötü sonucundan kaynaklanan bir düşünceyle, M. L. Crassus'un gereksiz yere böyle bir girişimde bulunduğu izlenimi oluşturmak için bunu vurgulama gereği duymuştur. Kendisine yapılan methiyeler sonucunda şuurunu kaybettiğini, Armenia ve Karadeniz krallarına karşı yapılan seferleri çocuk oyuncağı olarak görmeye başladığını ve hatta Afkanistan ve Hindistan'ı gözüne kestirdiğini dillendirme gereği duymaktadır ${ }^{49}$. Appianos ve Cassius Dio, aynı zamanda onun ganimete dayalı kar elde etme arzusu doğrultusunda Parthlara karşı savaşa giriştiğine işaret etmektedir. ${ }^{50}$

Aslında M. L. Crassus'un Parthlara saldırmadan önce Syria'da yaptığı talan faaliyetleri bunun bir göstergesidir. Syria'da iken, Parthlara karşı nasıl sonuç alıcı bir strateji uygulayabileceği ve bu doğrultuda askerlerine nası bir eğitim verebileceği gayretinden daha çok, öncelikli olarak ganimeti ve kendisini finansal açıdan daha fazla zenginleştirmeyi arzuladığı görülmektedir. Hem Syria eyalet kentleri hem de Hierapolis'teki tapınaktan elde ettiği paraların dikkatlice stoklanmasını sağlamıştır. Huzuruna davet edilen bölge halkları ve hanedanlardan sadece asker desteği değil, peşin para desteğini de kabul ettiğinden, bölgedeki yerel güçler ona karşı nefret beslemeye başlamışıı ${ }^{51}$. Hatta onun hırsından dolayı bu yerel güçlerden bazıları, daha sonra gerçekleşecek M. L. Crassus'un seferi sırasında Parthlarla gizliden işbirliği yapmayı tercih etmiş ve Roma ordusunu tuzağa sürüklemişlerdir. losephos, M. L. Crassus'un lerusalem'deki tapınağı da talan ettiğini, onbin talanta civarında oldukça fazla miktarda para gasp etttiğini bildirmektedir ${ }^{52}$. Neticede kendisine temel olarak Syria valiliği verilen M. L. Crassus, insiyatif kullanmış, aşııı para hırsı ve kibiri yüzünden gereksiz yere Parthlara karşı savaşa girişmiştir, ancak MÖ 53 yılında Carrhae'da Roma tarihinin en ağır yenilgilerinden birisine uğramıştı ${ }^{53}$. Parthlar, özellikle ağır zırhlı süvari birlikleri (kataphraktes), teknolojik açıdan üstün Roma kalkanlarını bile delebilen ok uçları, at üstünde çok iyi ok kullanabilme becerileri ve düşmanı tuzağa düşüren savaş taktikleri sayesinde Roma'nın Euphrates Nehri'nin ötesinde de sınırlarını genişleterek emperyalist amaçlarını gerçekleştirmesini uzun süre engellemiştir ${ }^{54}$.

\section{Sonuç}

Roma emperyalizmiyle ilgili olarak üzerinde durulması gereken birincil unsur sürekli savaş uygulamasıdır. Roma, MÖ 510 yılında Cumhuriyetin kurulmasından itibaren yaptığı önemli savaşların tamamını zamana yaymasını bilmiş ve nihayetinde başarılı sonuçlar elde etmiştir: Roma-Latin Savaşları (MÖ VII. yüzyıl- 338); Samnit Savaşları (MÖ 343-290); Pyrrhus Savaşları (MÖ 280-275); Kartaca Savaşları (MÖ 264-146); Makedonya Savaşları (MÖ 214-148); lugurtha Savaşları (MÖ 112-106); Mithradates Savaşları (MÖ 88-63). Genelde bilinçli olarak yayılmacı, saldırgan bir tavır sergilemiş ve gerektiğinde kural tanımadan bu savaşlara girişmiştir. Bu savaşlar sayesinde maddi ganimet ve çok sayıda kölenin yanısıra, yeni kurulan ve merkezden doğru-

Crassus’a kararname ile verildiğini” bildirmektedir. Ayrıca bkz. Flor. II. 13. 10.

Plut. Cras. XVI. 3.

49 Plut. Cras. XVI. 2.

50 App. Bel.Civ. II. 3. 18; XL. 12. 1-2.

51 Plut. Cras. XVII. 5.

52 Ioseph. Bel. Iud. I. 179; Ant. Iud. XIV. 105-106. Aynı zamanda bkz. Oros. hist. VI. 13. 1; Zon. epit. hist. V. 7; Heg. I. 21.2.

53 Özellikle bkz. Flor. I. 46. 1-6. Bu konudaki bütün sorumluluğun onun üzerine atılamayacağı, aslında G. Pompeius Magnus ve G. I. Caesar'ın da siyasi rakiplerine darbe indirmek için onu sonucu kestirilemeyen bu zorlu savaşı yapma konusunda kışkırtmış olabileceği tezi üzerinde bkz. Demir 2018, 234-346.

$54 \mathrm{M}$. Antonius'un yaklaşık on beş sene sonra gerçekleştirdiği Parthia Seferi'de başarısızlıkla sonuçlanmıştır. Bkz. Demir 2019, 149-169. 
dan yönetimin kabul ettirildiği eyaletlerde Roma vatandaşlarının toprak sahipliğine dayalı büyük karlar elde edilmiştir. Bu arada Romalı işadamları bu eyaletlerde faiz karşılığı krediler vererek, yeraltı ve yerüstü kaynaklarının ticaretini yaparak da refah seviyelerini artırmışlardır. Ekonomi sürekli savaşlarla beslendiğinden, Roma yönetim mekanizması savaşları kendi çıkarları doğrultusunda çıkarma, yürütme ve sonuçlarından faydalanma konusunda çeşitli yöntemler geliştirmiştir. Bunlardan birisi düşman topraklarına yakın koloniler kurmak ve bunlara Roma vatandaşIığı gibi çeşitli imtiyazlar vermek ve bunlar aracılığı ile düşmanını tahrik etmektir. Diğeri rakip kentlere farklı farklı imtiyazlar vererek, güç dengelerini ve ikili ilişkilerini bozmak, onları çatıştırarak güçsüz kılmak ve kendisine muhtaç duruma düşürmektir. Üçüncüsü birinden yana taraf olarak düşman devletlerin iç çekişmelerini körüklemek, yani içeride partizan grup çatışmalarını tahrik ederek bu devletlerin siyasi yapılarını ve ekonomilerini istikrarsızlaştırmak, güçsüz kılmaktır. Dördüncüsü el altından destek verilen korsanlar, haydutlar veya paralı askerler aracılığı ile istikrarsızlaştırma yöntemidir. Buradaki amaç hem rakip yönetimlerini dış tehditlerle veya içeriden bölerek zayıflatmak hem de buralarda kendi çıkarlarını devam ettirecek yönetimler kurdurmaktır. Bu bağlamda Roma, genelde kendi çıkarlarını gözetmeye devam edecek elitler veya krallar aracılığı ile bu sömürü düzenini devam ettirmeye çalışmıştır. Karşı ı̧ıktıkları durumda da gereğini yapmış ve alternatif yöneticileri işbaşına getirmek için yeniden istikrarsızlaştırma siyaseti uygulamıştır. 


\section{BİBLIYOGRAFYA}

\section{Antik Kaynaklar}

Amm. Marc.

App. Bel.Civ.

App. Mith.

Caes. Bel.Civ.

Cass. Dio

Cic.

Agr., Att., Catil., Phil., Pis., Man. Verr.

Eutr.

Flor.epit.

Heg.

loseph. Ant. lud.

loseph. Bel.lud.

Liv.

perioch.

Oros.hist.

Plut.

Ant., Caes., Crass., Luc., Pomp.

Poly.

Ps.-Aur. Vic. De Vir. II.
(= Ammianus Marcellinus, Rerum Gestarum Libri). Ammianus Marcellinus. Trans. J.C. Rolfe I-III. Cambridge, Mass.-London 2000 (The Loeb Classical Library).

(= Appianus, Bellum Civile). The Civil Wars. Trans. H. White. London 1899. (= Appianus, Mithridatica) Appian. The Foreign Wars. With an English Translation by Horace White. New York 1899.

(= Caesar, De bello Civili). The Civil Wars. Trans. A.G. Peskett. Cambridge, Mass.-London 1957 (The Loeb Classical Library).

(= Cassius Dio, Rhomaika). Roman History. Trans. E. Carry, vols. I-IX. London 1914-1927 (The Loeb Classical Library).

(= Cicero, De Lege Agraria, Epistulae ad Atticum, In Catilinam, Orationes, Philippicae in M. Antonium, In Pisonem, De imperio Cn. Pompei, In Verrem) Kullanılan Metin ve Çeviriler: Letters to Atticus. Ed. \& Trans. D. R. S. Bailey, vol. I-IV. Cambridge, Mass.-London 1999; Phillippics. With an English Translaton by W. C. Ker. Cambridge, Mass.- London 1995 (8); Against Lucius Calpurnius Piso. With an English Translation by N.H. Watts. Cambridge, Mass.-London 1992 (7). (The Loeb Classical Library); Against Catilina. M. Tullius Ciceco The Orations of Marcus Tullius Cicero, literally translated by C. D. Yonge, B. A. London. Henry G. Bohn, York Street, Covent Garden. 1856; 1903.

(= Eutropius, Brevarium ab Urbe Condita of Eutropius). Translated with an Introduction and Commentary by H. W. Bird. Liverpool 1993.

(= Annius Florus, L. Annaei Flori Epitoma De Tito Livio Bellorum Omnium Annorum DCC Libri II). Lucius Annaeus Florus. The Two Books of the Epitome, Extracted from Titus Livius, of All the Wars of Seven Hundred Years. Trans. E. S. Foster. London/New York 1929 (The Loeb Classical Library).

(= Hegesippus). Hegesippus. With an English Translation by W. Blocker. wblocker@nmol.com.2005.

(= Flavius losephus Historicus, Antiquitates ludaicae). The Jewish Antiquities. Trans. H. St. J. Thackeray, vols. IV-IX. London/New York 19301939 (The Loeb Classical Library).

(= Flavius losephus Historicus, Bellum Iudaium). The Jewish War. Trans. H. St. J. Thackeray, vols. II-III. London/New York 1927-1928 (The Loeb Classical Library).

(Livius, Ab Urbe Condita)

(= Ab urbe condita Librorum periochae). Livy, From the founding of the city. Trans. A. C. Schlesinger, vols. I-XIV. London/New York 1967 (The Loeb Classical Library).

(= Orosius, Historiarum adversus paganos libri VII). Seven Books of History Against the Pagans. Translated with introduction and notes by I. W. Raymond. New York 1936.

(= Plutarkhos, Antonius, Caesar, Crassus, Lucullus, Pompeius)

Kullanılan Metin ve Çeviriler: Plutarch. Plutarch's Lives. Trans. B. Perrin, vols. I-XI: London, New York 1959 (The Loeb Classical Library).

(= Polybios, Historiai). The Histories. With an English Translation by W. R. Paton, Vols. I-VI. Cambridge, Mass.- London 1922 VD (The Loeb Classical Library).

(= Pseudo Aurelius Victor, De viris illustribus urbis Romae). De viris illustribus urbis Romae. Ed.: F. Pichlmayr. Leipzig 1911. [Teubner] [http://www.forumromanum.org/literature/aurelius_victor/illustr.html]

Les Hommes Illustres de la Ville de Rome. With a French Translation by M.-P. Arnaud-Lindet. 2004. 
Sall. Hist.

Strab.

Tac. Agr.

Vell. Patt.

Zon. epit.hist.

\section{Modern Kaynakça}

Arslan 2002

Arslan 2003

Arslan 2007

Beard - Crawford 1985.

Beek 20015

Brunt 1965

Cornell 1995

Crawford 1993

Crawford 1996

De Souza 1997

De Souza 1999

De Souza 2008

Demir 2011

Demir 2018

Demir 2019

Dimitriev 2000

Dimitriev 2009 [http://www.forumromanum.org/literature/aurelius_victor/illustrf.html] (= Sallustius, Historiae). Sallust, The Histories. Translated with introducton and commentary by P. McGushin, Vol. I-II, Oxford 1992, 1994.

(= Strabon, Geographika). The Geography of Strabo. Ed. H. L. Jones, vols. IVIII. Cambridge, Mass.- London 1924.

(= Tacitus, Agricola). Complete Works of Tacitus. Edited by S. Bryant for Perseus. New York 1876. Reprinted 1942.

(= Velleius Paterculus, Historia Romana). Velleius Paterculus. Roman History. Trans. F. Shipley. Cambridge, Mass.- London 1924 (The Loeb Classical Library).

(= Ioannes Zonaras, Epitome Historiarium). The History of Zonaras: From Alexander Severus to the Death of Theodosius the Great. With an English Translation by E. Lane. London 2009.

M. Arslan, "I. Mithridates-Roma Savaşı: Rhodos ve Lykia'nın Durumuna Genel Bakış". Şurada: Lykia incelemeleri 1. Eds. S. Şahin et al., İstanbul (2002) 115-128.

M. Arslan, "iÖ. 188 Yılından iÖ. 67 yılına Kadar Lykia, Pamphylia ve Kilikia Trakheia Sahillerindeki Korsanlık Faaliyetleri: Nedenleri ve Sonuçları". Adalya VI (2003) 91-118.

M. Arslan, Mithradates VI Eupator: Roma'nın Büyük Düşmanı. İstanbul 2007.

M. Beard - M. Crawford, Rome in the Late Republic: Problems and Interpretations. London 1985.

A. L. Beek, Freelance Warfare and Illegitimacy: the Historians' Portrayal of Bandits, Pirates, Mercenaries and Politicians (PhD Thesis), University of Minnesota 2015.

P. A. Brunt, "Reflections on British and Roman Imperialism". Comparative Studies in Society and History 7/3 (1965) 267-288.

T. J. Cornell, The Beginning of Rome. Italy and Rome from the Bronze Age to the Punic Wars (c. 1000-264 BC). London/New York 1995.

M. H. Crawford, The Roman Republic. Second Ed. Harvard University Press 1993.

M. H. Crawford, Roman Statutes I. London 1996.

P. De Souza, "Romans and Pirates in a Late Hellenistic Oracle from Pamphylia". Classical Quarterly 47/2 (1997) 477-481.

P. De Souza, Piracy in the Graeco-Roman World. Cambridge 1999.

P. De Souza, "Rome's Contribution to the Development of Piracy". Memoirs of the American Academy in Rome 6 (2008) 71-96.

M. Demir, "Antik Kaynaklar Işığında III. Attalos'un Vasiyeti". Eds. E. Önen -

M. Mutluer - N. Çetin, Uluslararası Bergama Sempozyumu Bildiriler Kitabı, 7-9 Nisan 2011, 1. Cilt. İzmir (2011) 179-199.

M. Demir, "Carrhae Savaşı'nın (MÖ 53) Sebepleri ve Sonuçları Üzerine Bazı Değerlendirmeler". Cedrus VI (2018) 233-248.

M. Demir, "Marcus Antonius'un Parthia Savaşı'n ın (MÖ 40-33) Sebepleri ve Sonuçları Üzerine Bazı Değerlendirmeler". Tüba-Ar 24 (2019) 149-169.

S. Dimitriev, Local Administration in the Province of Asia, The Problem of Roman Influence. Harward University/Cambridge/Massachusetts 2000.

S. Dimitriev, "(Re-)constructing the Roman empire: from 'imperialism' to 'post-colonialism'. An historical approach to history and historiography". Annali della Scuola Normale Superiore di Pisa. Classe di Lettere e Filosofia, Serie 5 1/1 (2009) 123-164. 
Errington 1971

Frank 1914

Gruen 1984

Harris 1979

Harrison 2008

Hobson 2016

Hopkins 1978

Hopkins (1981)

Isaac 1990

Kallet-Marx 1995

Lomas 1996

Mommsen 1984

Richardson 1976

Sidebottom 2005

Sherwin-White 1984

Taylor - West 1928

Walbank 1963

Welles 1934
R. M. Errington, The Dawn of Empire: Rome's Rise to World Power. London 1971.

T. Frank, Roman Imperialism. New York 1914.

E. S. Gruen, The Hellenistic World and the Coming of Rome. Berkeley/Los Angeles/London 1984.

W. V. Harris, War and Imperialism in Republican Rome 327-70 BC. Oxford 1979.

T. Harrison, "Ancient and Modern Imperialism". Greece \& Rome 55/1 (2008) 1-22.

M. S. Hobson, "Roman imperialism in Africa from the Third Punic War to the battle of Thapsus (146-46 BC)". Eds. N. Mugnai-J. Nikolaus - N. Ray, De Africa Romaque: Merging cultures across North Africa. London (2016), 103-120.

K. Hopkins, "Economic Growvth and Towns in Classical Antiquity". Eds. P. Abrams - E. A. Wrigley, Towns in Societies: Essays in Economic History and Historical Sociology. Cambridge University Press (1978) 35-77.

K. Hopkins, Conquerors and Slaves. Cambridge University Press 1981.

B. Isaac, Limits of Empire. The Roman Army in the East. Oxford 1990.

R. M. Kallet-Marx, Hegemony to Empire. The Development of the Roman Imperium in the East from 148 to 62 BC. Berkeley/Los Angeles/Oxford 1995. K. Lomas, "Greeks, Romans, and Others: problems of colonialism and ethnicity in southern Italy". Eds. J. Webster - N. Cooper, Roman imperialism. Post-colonial perspectives 3. Proceedings of a symposium held at Leicester University in November 1994. Leicester (1996), 135-144.

T. Mommsen, The History of Rome, Vol. V. Trans. W. P. Dickson. London 1984.

J. S. Richardson, "The Spanish Mines and the Develepmont of Provincial Taxation in the Second Century BC". Journal of Roman Studies 66 (1976) 139-152.

H. Sidebottom, "Roman Imperialism: The Changed Outward Trajectory of the Roman Empire". Historia: Zeitschrift für Alte Geschichte 54/3 (2005) 315-330.

A. N. Sherwin-White, Roman Foreign Policy in the East 168 B.C. to A. D. 1. Norman 1984.

L. R. Taylor - A. B. West, "Latin Elegiacs from Corinth". American Journal of Archaeology 32/1 (1928) 9-22.

F. W. Walbank, "Polybius and Rome's Eastern Policy". Journal of Roman Studies 53 (1963) 1-13.

C. B. Welles, Royal Correspondence in the Hellenistic Period. London 1934. 